\title{
Relational Economies, Social Embeddedness and Valuing Labour in Agrarian Change: An Example from the Developing World.
}

\author{
George N. Curry and Gina Koczberski, \\ Department of Social Sciences, Curtin University of Technology, GPO Box U1987, Perth, \\ WA 6845, Australia
}

The reference for this article is:

Curry, G.N. and Koczberski, G. (2009). Relational Economies, Social embeddedness and valuing labour in agrarian change: an example from the Developing World. Geographical Research 50(4), 377-392.

Please note that there may be some minor differences between this PDF version of the paper and the published article. Reprints of this article can be obtained from George Curry <g.curry"at"curtin.edu.au $>$

\begin{abstract}
A relatively neglected area of research on agrarian and economic change is the role of indigenous concepts of labour value in the transition from subsistence to market production. In West New Britain Province, Papua New Guinea, the presence of a migrant population on an oil palm land settlement scheme (LSS) in close proximity to village-based oil palm growers, provided an opportunity to examine changing notions of labour value through the lens of smallholder productivity. Voluntary settlers on the LSS are experiencing population pressure and are highly dependent on oil palm for their livelihoods. In contrast, customary landowners in village settings produce oil palm in a situation of relative land abundance. By examining differences in how these two groups practise and value commodity production, the paper makes four key points. First, concepts of labour value are not static and involve struggles over how labour value is defined. Second, the transition to market-based notions of labour value can undermine labour's social value with a consequent weakening of social relationships within and between families. Third, Theories of Value developed in western contexts and used to frame development policies and projects in the developing world are often inappropriate and even harmful to the welfare of communities that have different registers of value. Fourth, in response to Point 3, and following Rigg (2007), there is a need for 'theorising upwards' using empirical data from the developing world to inform theory rather than applying to the developing world models of sociality and economy developed in western contexts.
\end{abstract}

KEY WORDS social embeddedness; relational economy; agrarian change; socio-cultural change; smallholder cash crops; performativity; labour value

\section{Introduction}

This paper extends relational concepts of economy to examine labour value, a key theoretical concept in development, especially in the promotion and facilitation of market-based development such as export commodity crops. By extending relational concepts of the economy to valuing labour, the paper brings into analysis labour's social value. This enables 
us to move beyond under-socialised and universal theories of labour value such as the Marxist theory of labour value or the supply and demand determinants of neo-classical economics that have influenced much of the writing on, and interpretation of, socioeconomies in both developed and developing countries. By unpacking these other values, which are intimately bound up in local constructions of sociality and economy, we can gain better insights for theorising about processes of socio-economic change and meanings of development in the developing world.

To explore alternative notions of labour value, we draw on recent advances on the social embeddedness and relational dimensions of economy, and on our fieldwork in Papua New Guinea (PNG) over many years. Much of this work on relational perspectives of economies is an outcome of cross fertilisation of disciplinary perspectives, especially from sociology and anthropology, and has considerable potential to contribute to new theoretical concepts in development geography and development practice more generally. Whilst the literature on the social embeddedness of economic activity is beginning to stimulate discussions in geography on the relational aspects of the economy, it remains rare for geographers to conceive of alternative notions of labour value.

Alternative ways of valuing labour that are discussed in this paper arise from several sources: (1) labour's performance as distinct from its product; (2) its value as an item in the gift economy directly, that is, its value outside the market economy (the gift of labour); and (3) labour's indirect value in the gift economy as its exchange value in the market economy is realised to acquire cash, commodities, or other items that are subsequently transformed into gifts during later circuits of exchange. These other values of labour are determined by, and determine, personhood and individual and group social identity. They also determine the extent of engagement of labour in commodity production which has implications for agricultural development projects aimed at increasing smallholder income by raising labour productivity.

To explore alternative notions of labour value, the paper presents a case study of two groups of oil palm smallholders in West New Britain Province, PNG: migrant settlers who have been removed from their village socio-economies, and customary landowners living in nearby villages where indigenous social and economic networks and cultural practices are still central to everyday life. The case study examines how indigenous ways of valuing labour interact with commodity production and exchange to influence farming strategies and shows how changing concepts of labour value under recent rapid socio-economic and cultural change are leading to shifts in indigenous and intra-household relations of production and the way smallholders produce oil palm. For one group of smallholders - settlers on an oil palm land settlement scheme - concepts of labour value are in a state of flux as their cash needs increase because of economic/land pressure and as the allure of modernity leads to changing aspirations, thereby altering pre-existing indigenously defined generational and kinship-based determinants of labour value. We return to consider the implications of the findings for development theory and practice in the concluding discussion.

\section{Social embeddedness, relational concepts of economy, and labour value}

Concepts of the social embeddedness of the economy have a long history in the social sciences from the early work of Malinowski (1919) and Mauss ([1925] 1974) on gift exchange through Karl Polanyi's (1944; Polanyi et al., 1957) insightful work on the social embeddedness of economies, to a diverse array of recent approaches (see further discussion). Polanyi's pioneering work revealed that how an economy is constituted depends on the way it 
is embedded in society, thereby allowing for a range of possible economic-societal formations (see Granovetter, 1985; Zukin and DiMaggio, 1990; Hefner, 1998; Block, 2001). He also drew attention to the multiple logics operating simultaneously in economic decisionmaking, which belie the presumed social neutrality of economic transactions and decisionmaking that inform both structuralist and functionalist interpretations of economy (Swedberg, 1994). Research on the social dimensions of economic activity has demonstrated, for example, the importance of social networks for building trust and channelling knowledge and information which are ultimately implicated in business success at a variety of spatiotemporal scales (for example, Platteau, 1994a; 1994b; Amin and Thrift, 1995; Mistal, 1996; Thrift and Olds, 1996; Leyshon et al., 1998; Yeung, 2005; 2009; Sidaway, 2007; Turner, 2007).

With the rise of poststructural approaches, Polanyi's work is becoming more influential in geography and contributing to new ways of thinking about economy and society (for example, Thrift, 1996; Leyshon, 1997; Hart, 2001; Bahelt and Glückner, 2003; Boggs and Rantisi, 2003; Curry, 2003; 2005; Ettlinger, 2003; Hess, 2004; Kirwan, 2004; Gill, 2005; Hughes, 2005; Smith and Stenning, 2006). Gibson-Graham's diverse economies group employs an anti-capitalocentric discourse to make visible non-capitalist practices and relations that have been obscured by a capitalocentric discourse (Gibson-Graham, 1996; McKay, 2009). While perhaps a little too uncritical of the capacity of non-capitalist practices to sustain exploitative gendered and generational relations, the approach is clearly based on concepts of social embeddedness.

Another group encompasses an array of approaches that could loosely be called the hybrid economies perspective (Nederveen Pieterse, 1994; Nabudere, 1997; Simon, 1998; 2007; Perreault, 2003), which has some parallels with postdevelopment theory (Crush, 1995; Escobar, 1995; Rahmena and Bawtree, 1997; Esteva and Prakesh, 1998; Nederveen Pieterse, 2000). Postdevelopment theory, like the hybrid economies perspective, challenges the universalism and reductionism of western-derived models of development. However, where postdevelopment seeks to reject development, the hybrid economies perspective recognises that a diverse set of logics can co-exist simultaneously and that introduced elements of the market economy can be conditioned by indigenous economic and social logics. In the Pacific, an extensive literature recognises that a range of alternative modernities can emerge. Much of this research has stressed the role of indigenous or pre-colonial economic logics and social values in shaping contemporary forms of socio-economy and values (for example, Carrier and Carrier, 1989; Thomas, 1991; Banks, 1999; Goddard, 2000; Imbun, 2000; van der Grijp, 2004; Sahlins, 2005; Barclay, 2006; Minnegal and Dwyer, 2007; Cahn, 2008; Curry and Koczberski, 2009; Thornton et al., 2010; Bainton, 2011). These approaches have done much to counter metanarratives of an all powerful globalising and totalising capitalism that contaminates or obliterates non-capitalist socio-economic forms.

While some readings of social embeddedness of economies might be considered instrumentalist in the sense that they are read solely for their material significance, such as their capacity to generate income or profits, it is also important to recognise that they generate other forms of value which, while less tangible, generate significant value in terms of emotional well-being and life satisfaction for individuals and communities. Moreover, the concept of social embeddedness is sometimes construed as showing that the economy and society can be separate entities. For instance, Jones (2008) questions the usefulness of the concept of social embeddedness because he argues that it allows a separation of the two, when they cannot be separated. However, in economic geography there is growing 
recognition of the inseparability of society and economy: '... the economy is intensely social and the social is intensely economic' (Curry, 2003, 419; see also Lee, 2006). In this paper, we use the concept of embeddedness as a tool for examining the strength of co-constitution of economic and social forms.

Recent explorations of the social embeddedness of economic activity are leading to a growing, though still nascent, theoretical sense of the relational aspects of the economy and associated alternative notions of labour value. However, as Lee $(2006,417)$ points out, 'an explicit entanglement with value is relatively rare in economic geography'. Perhaps this is so because universal theories of labour value have held so much sway in the discipline that other conceptions of labour value have not been given much consideration. Despite the rise of poststructuralist perspectives, the Marxist theory of labour value and concepts of labour value from neo-classical economics are perhaps so deeply ingrained in our thinking that it is difficult to conceive of other notions of labour value. In attempting to overcome constraints on thinking about value, Lee $(2006,415)$ identifies three linked notions of value as follows:

- value - the ... life-sustaining things, ideas, relations and practices consumed, exchanged, and produced in circuits of value;

- Theories of Value - transcendent interpretations of the origins and nature of Value (such as those deriving from labour or energy Theories of Value, for example) brought to bear on, and contested in, the practice, performance, and regulation of economic life;

- values - the forms of life, relations, things, thoughts, and practices that are held dear and are considered to be inalienable.

For Lee's first notion of value (life-sustaining value), this may take multiple forms, including ideas, money, labour power, things, etc. The question for Lee is how value, values, and societal reproduction are linked, and what this means for Theories of Value, which 'may, or may not, be validated in social practice or imposed in political practice.' $(2006,415)$. On a related point, Lee asserts that: '[i]f value is to be exchanged, it must be valued by both producer and consumer and hence validated in terms of social reproduction ... many different notions of Value may serve this purpose.' $(2006,416)$. For us, this suggests three key points that are relevant to our PNG research: (1) notions of value may be contested; (2) when values change, then validation may not occur as competing notions of value jockey for ascendancy; and (3) universal theories of value are not the only yardsticks for measuring value, a point, of course, that was recognised by Marx himself.

Miller (2008) also reminds us that some anthropologists, like Strathern (1990), have accepted that it is difficult to reconcile a Marxian universal source of labour value with relativist conceptions of labour:

in some regions there is neither evidence nor reason to conceive of value as based in labour, and that a population is neither deluded or ideologically warped in refusing to see value from this perspective. (Miller, 2008, 1123).

Both Lee and Miller's views are relevant to our case study of changing notions of labour value and we shall return to these issues later in the paper. 


\section{Networks of exchange and reciprocity - the gift-commodity distinction}

To bring into focus other sources of value in our analysis of smallholder oil palm and to highlight the co-constitution of the social and the economic, we use as a heuristic device the conceptual framework of the gift-commodity distinction to tease out alternative notions of value that have been overshadowed by universal theories of labour value. Table 1 summarises key differences between gifts and commodities. The gift-commodity distinction is a useful concept for it enables us to make alternative readings of production, distribution and exchange to understand how these are implicated in different forms of value concerned with constructions of identity and personhood. Like social embeddedness, the gift-commodity distinction is sometimes understood as an immutable duality involving two distinct sets of socio-economic relationships and values. We adopt a less rigid distinction in which the varying social contexts of transactions can shift the meaning of an exchange in either direction along a gift-commodity continuum. As Gregory $(1982,116)$ states: '[a] thing is now a gift, now a commodity, depending on the social context of the transaction. ... things assume different social forms at different times and in different places'.

Table 1. Key characteristics of gifts and commodities at each end of the gift-commodity continuum.

\begin{tabular}{|l|l|}
\hline \multicolumn{1}{|c|}{ Gift transactions } & \multicolumn{1}{c|}{ Commodity transactions } \\
\hline Item exchanged is inalienable & Item exchanged is alienable \\
\hline $\begin{array}{l}\text { Social act (in certain contexts can be an } \\
\text { asocial or aggressive act) }\end{array}$ & Non-social act \\
\hline $\begin{array}{l}\text { Reciprocal dependence between } \\
\text { transactors }\end{array}$ & $\begin{array}{l}\text { Reciprocal independence between } \\
\text { transactors }\end{array}$ \\
\hline $\begin{array}{l}\text { Individual or group is the transacting party } \\
\text { Social relationships between } \\
\text { transacting individuals created or } \\
\text { maintained }\end{array}$ & $\begin{array}{l}\text { Individual including individual business } \\
\text { entity (e.g., firm) is the transacting party }\end{array}$ \\
\hline $\begin{array}{l}\text { Transaction alters the social relationship } \\
\text { between the social groups with which } \\
\text { each party to the transaction is affiliated }\end{array}$ & $\begin{array}{l}\text { Does not alter the social relationship } \\
\text { between transacting individuals } \\
\text { relationships between the social groups with w } \\
\text { each party to the transaction is } \\
\text { affiliated }\end{array}$ \\
\hline $\begin{array}{l}\text { Future social and economic obligations } \\
\text { created }\end{array}$ & $\begin{array}{l}\text { No future social and economic obligations } \\
\text { created }\end{array}$ \\
\hline Important for creation of social identity & Not important for social identity \\
\hline Labour value may not be important & Labour value is important \\
\hline III-defined boundary of proprietary interests & Unified bounded entity \\
\hline Inclusive ownership & Exclusive ownership \\
\hline
\end{tabular}

The ambiguity between gifts and commodities means that for any given exchange transaction, there is potentially a commodity value and a gift value, with the two values present within the one transaction. This paradoxical situation arises because of the different way that both parties to an exchange transaction view and vest meaning and value in that transaction. While it is likely in most cases both parties will view relative values in the same way because of their shared cultural and social backgrounds, the possibility remains that one 
party may see the transaction weighted more as a commodity transaction while the other sees it weighted towards a gift transaction. For example, a villager who purchases an item in a foreign-owned store in town is unlikely to perceive any gift value in the transaction, and nor will the store proprietor, but the same transaction made in a village store managed by a relative is likely to have a much higher gift value (Curry, 1999). What is important, however, is that the relative weight of the gift value vis-à-vis the commodity value will be highly context dependent and may be contested, especially during periods of rapid socioeconomic and cultural change.

One must not assume that because gift transactions are not market transactions and the items exchanged have often not been produced under capitalist relations of production, they must therefore be inherently more equitable, fairer or nobler than capitalist relations of production or market exchange relations. Gift exchange can be an effective mechanism for the systematic reproduction of socio-economic inequalities and status hierarchies across generations, genders and kinship groups (for example, Carrier and Carrier, 1989; Nihill, 1991; Weiner, 1992; Curry, 1997). As Sahlin's remarked, 'everywhere in the world the indigenous category for "exploitation" is "reciprocity" ' $(1972,134)$.

\section{Field site}

Fieldwork was carried out among oil palm smallholders in the Hoskins oil palm project area on the north coast of West New Britain Province (WNB) (Figure 1). With over 55000 ha planted to oil palm, the industry dominates the rural economy and oil palm is by far the most important smallholder commodity crop.

Commercial plantings began at Hoskins in the late 1960s following a World Bank recommendation that oil palm on a nucleus estate-smallholder model be introduced to WNB to diversify the agricultural economy and increase the export income of PNG (Koczberski et al., 2009). The model allowed for the establishment of smallholder land settlement schemes (LSSs), initially at Hoskins in 1968 and then at Bialla in 1972. Settlers were recruited to the LSSs from many parts of PNG and acquired individual 99 year state agricultural leases over blocks ranging from 6 to 6.5 ha. Since the establishment of the Hoskins LSS, population density has risen from 5.9 persons per block in the 1970s to 13.3 per block in 2000 to an estimated 18 persons per block in 2010. Rapid population growth has led to considerable social and economic pressures particularly when oil palm prices are low.

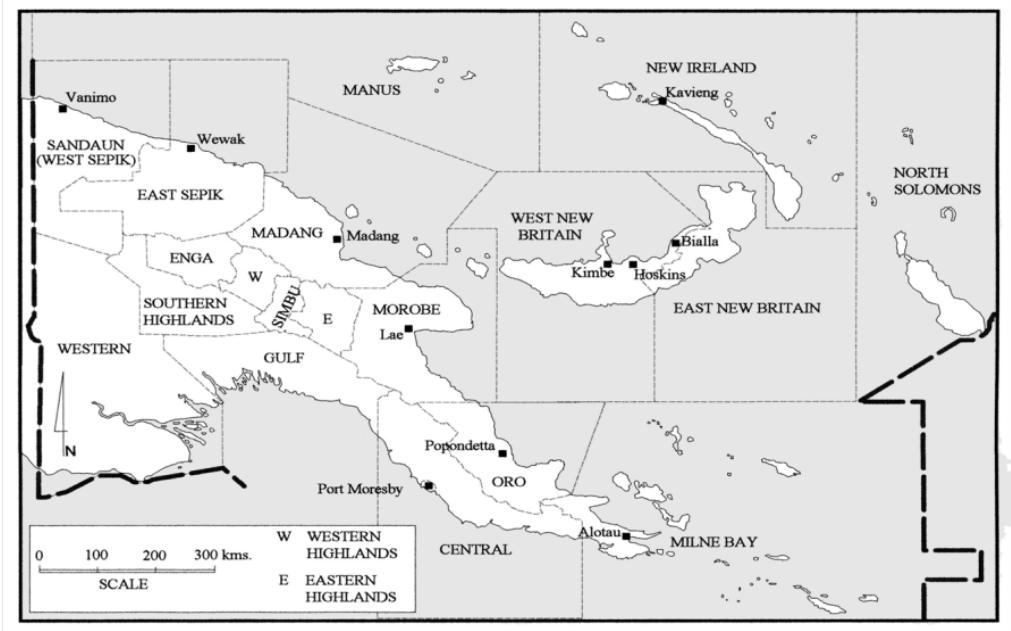

Figure 1. Papua New Guinea. 
The LSSs were viewed as major vehicles for increasing export agricultural production, integrating Papua New Guineans into cash crop production, and as a way to relieve population pressures in some rural areas (Hulme, 1984). The Australian Administration also considered that the establishment of LSSs would lead to an individualised land tenure system that would replace customary land tenure grounded in kinship (Hulme, 1984). It was also assumed that the resettlement of Papua New Guineans on LSSs would induce a switch from a subsistence-based economy to a market economy in which the production of export cash crops would encourage smallholders to become intensive agriculturalists working their own land. In this vision, settlers through their experiences on the LSSs, would come to realise the social and economic benefits of individualised land tenure and market relations of production and exchange. It was thought that the LSSs would provide a model of development that would, in time, spread to other regions of PNG.

This vision of nuclear families working their own land ran counter to the extended family networks involved in subsistence production where the primary motivating forces were not profit driven. The realisation of the vision therefore relied on the transformation of not only indigenous values regarding land tenure and relations of production, distribution and exchange, but also an ontological transformation of the very nature of social being and identity grounded in relational identities. For the administration, the vision would overcome the common western view at the time of indigenous people in the developing world: the indolent native as an economically irrational decision-maker, poorly skilled, uneducated, superstitious and lacking commitment to export cash crop production.

As the industry expanded with company plantation development and settlers producing oil palm on the LSS, village families living on customary land surrounding the nucleus estates were encouraged to plant 2 ha plots of oil palm as part of the Village Oil Palm (VOP) scheme. Planting by customary landowners was negligible in the early years, but has increased significantly over the past 20 years, especially since the decline of cocoa and copra as cash crops. Most VOP growers are involved in a diverse range of livelihood activities in addition to oil palm production. They also remain very much engaged in the subsistence economy and much of the village cultural infrastructure remains intact.

\section{Methods}

The qualitative data underpinning the study draws on several fieldtrips to WNB from 1994 to 2008. Qualitative data were obtained using a range of methodologies including: (1) informal interviews with LSS and VOP smallholder households; (2) collection of smallholder household biographies; (3) field observations of smallholders working in their oil palm plots and food gardens, and (4) structured interviews with key agricultural extension managers/officers of the Oil Palm Industry Corporation (OPIC), the government agricultural extension services for smallholder farmers. Qualitative data collection focused on developing an understanding of: inter- and intra-household relations of production and how they influenced the production and livelihood strategies of families; the meanings and values attached to labour and labour exchange; social mechanisms utilised to mobilise labour in commodity crop production; and changing indigenous and household labour relations of production. These qualitative data, involving extensive periods of fieldwork and ethnographic techniques, provided the contextual understanding for interpreting the quantitative production data presented later. 


\section{Production data}

Total monthly production data from March 1998 to October 2003 for plantations, settlers (LSS), and villagers (VOP) were collated from the company plantation database and the smallholder production and payment records. ${ }^{1}$ Monthly yield data for smallholders required calculating the area of smallholder oil palm in production each year by using palm census surveys undertaken periodically by the oil palm extension agency, OPIC (Oil Palm Industry Corporation). ${ }^{2}$ Total monthly production for plantations, settlers, and villagers was divided by area under cultivation to provide monthly yield data in tonnes per ha. These data were then smoothed with a 3 month moving average. Monthly prices received by smallholders for oil palm fruit paid over this period were obtained from OPIC records. These data were also smoothed with a 3 month moving average.

The five years of monthly yield data are for 15000 ha of plantations and 14326 ha of smallholders (4500 smallholder blocks of which 3000 were LSS settler blocks and 1500 were VOP blocks). The purpose of including the plantation data was to provide a baseline with which to examine variations in smallholder productivity through time while controlling for variability in production due to environmental factors. The plantation company applies all the inputs like fertiliser and pest control, and palms are fully harvested. Plantation production is what could be achieved by smallholders if they were to apply all the management inputs and fully harvest their palms.

\section{Oil palm and indigenous concepts of labour value}

Smallholders follow a fortnightly harvesting schedule, and Fresh Fruit Bunches (FFB) must be processed by the milling company within three days of being harvested, or oil quality declines. The heavy task of harvesting FFB is usually the work of men, with elderly males relying on their sons or other male relatives to harvest tall palms. FFB are carted by wheelbarrow to the roadside edge of the block where they are stacked in nets ready for collection by the milling company truck. The oil palm fruitlets (the 'loose fruit') that scatter on the ground after being dislodged from the main bunch during harvesting are gathered by females of all ages and are carried to the roadside collection point. Payment for FFB is made to the male 'owner'/ leaseholder, while women are paid for loose fruit (Koczberski, 2007).

Given the large amount of work associated with harvesting the typical 6 ha oil palm block in the fortnightly three-day window before a harvest pick-up, access to family and extrafamilial labour is critical for maintaining production. Co-operative intra- and inter-household labour amongst co-resident households underpins oil palm production. This type of labour mobilisation is referred to locally as wok bung wantaim (working together), at both an intraand inter-household level, with the participation of all or most adult members of co-resident households working together on an oil palm harvest. The wok bung wantaim production strategy is a highly centralised form of production whereby the male head of the block, typically the father and leaseholder, mobilises family and co-resident household labour, allocates specific harvesting tasks to family members, and is responsible for the distribution of oil palm income amongst labourers. The high level of labour cooperation ensures an adequate labour supply for harvesting, which is particularly important during high crop periods. ${ }^{3}$ For the wok bung wantaim production strategy to function successfully, the male head of the block requires skills in coordinating and managing labour, maintaining his authority on the block, and meeting his social obligations to people who provide labour.

The wok bung wantaim production strategy used in oil palm production emerged from the labour strategies underpinning subsistence production. Generally, for heavy, labour-intensive 
subsistence tasks such as the cutting, clearing, and fencing of new food gardens, the planting and harvesting of root crops, house building or the preparation of communal feasts, the lineage and often other members of the broader kinship group contribute labour. These large co-operative work groups in which the labour of the extended family and kinship group is mobilised to perform intensive agricultural or community work are commonly used by rural households in $\mathrm{PNG}^{4}$ (Waddell and Krinks, 1968; Hide, 1981; Modjeska, 1982; Foster, 1995). These same indigenous strategies for mobilising labour for subsistence production have been carried over into cash crop production to ensure an adequate labour supply for harvesting, which is particularly important during high crop periods. For village oil palm producers, and to a lesser extent, settler households (see further discussion), cooperative intra and interhousehold labour arrangements amongst co-resident households underpin oil palm production.

Labour contributions to subsistence production both structure and are structured by kinship and social relationships. They can be on a balanced reciprocal basis where a labour contribution is later reciprocated with a similar gift of labour as often happens amongst agnatic individuals and groups in patrilineal societies. Some are based on relationships of inequality where there is no obligation to reciprocate the labour contribution with a similar gift of labour. Relationships based on inequality often characterise those between wife-giving and wife-taking groups in which the latter can give labour without the expectation of a later reciprocation of labour. While relationships of inequality can lead to one party contributing labour without a material return, the other party, if giving labour, may receive a return in labour, cash, or wealth items that vastly exceeds the market value of the original labour contribution.

\section{Labour's value in oil palm production}

To understand the role of labour in PNG sociality, it is first necessary to acknowledge that labour does not operate in a vacuum separate from daily social life. Rather, labour sits within much wider networks of obligations and reciprocity within the household and extended kinship groupings that form part of the gift exchange and relational economy of PNG described earlier. Gift exchange is, therefore, the foundation upon which social relationships are established, affirmed, and expanded, the latter through enrolling individuals and groups in wider networks of identity. Through gift exchange, relationships amongst transacting individuals and their associated networks and groups are made or re-made. In these transactions, an intrinsic relation exists between the item of exchange and its donor, in that the exchange item can be conceptualised as constituting 'parts of persons' themselves (Strathern, 1990, 178). From this perspective, the gift contains the embodiment of the donor and is never fully alienated from the person as in commodity transactions (Mauss, [1925] 1974; Foster 1995; Goddard 2000). In summary then, it is in the sphere of gift exchange, which includes the giving and receiving of labour, that social order and social reproduction occur and where people's wellbeing is most prominently determined.

It is within these relational structures of sociality and economy that the culturally specific meanings and values attached to labour in oil palm are defined. In the eyes of smallholders, when a family member contributes labour to the household or group (wok bung wantaim), they are simultaneously reinforcing their relationship and connection to the household and other household members. When a husband and wife and other family members work cooperatively to harvest oil palm they are collectively reaffirming their relationships to each other. Likewise, someone providing labour to a brother, sister or an affine is expressing and nourishing her relationship with these kin. For this reason, members of the extended family 
and kinship group can be found assisting family members with a harvest or garden work when it is not necessarily the case that the relative sought help from their relative because of labour shortages. In this way, contributing labour to cooperative work activities in oil palm, is central to reproducing intra- and interhousehold relationships and is also a public expression of household solidarity and the continuing obligations amongst family members (Koczberski, 2011).

Accompanying the meanings and values attached to labour in export cash crop production is the view among smallholders that 'paying' for family labour (treating the family member as a wage labourer) inserts a dimension of commodity exchange considered antithetical to labour's social value. When labour is given in oil palm production, its value is derived from what it symbolises in terms of the specific relationship between the two parties and, therefore, cannot be equated directly with some monetary value. When relatives are given cash for assisting with oil palm production, smallholders are adamant that it is wrong to interpret these transactions according to principles of a market in hired labour or to assume that cash 'payments' are based on the value of the product of that labour. First, the cash given is not a 'wage' for work done. Rather, cash payments symbolise the grower's appreciation of the gift of labour, and recognise the type and status of the relationship between the grower and the person giving labour, the generous nature of the grower, and/or their acknowledgement of the needs of others. Thus, an important aspect of the co-operative wok bung wantaim strategy is that the 'payment' of labour does not necessarily reflect labour input but instead is governed more by gender, age, and kinship status, as well as by the perceived financial needs of individual family members in much the same way as labour is deployed and valued in the non-market subsistence economy.

By acknowledging the socially embedded nature of labour in oil palm it is evident that it is the social aspect of labour that gives labour its value, and not solely the abstract monetary value of the work performed or the value of the product of that labour. When labour in oil palm is given within the context of the gift economy, and by extension with its primary role in affirming relationships, then its value is specific to the persons giving or receiving the labour. These meanings attached to labour in oil palm are similar to the meanings of labour reported elsewhere in PNG (see Modjeska, 1982, 51-65; A. Strathern, 1982; Strathern, 1990; Fajans, 1993; Kuehling, 2005; Sillitoe, 2006). As Strathern observes in her study in the Hagen region of $\mathrm{PNG}$, 'there is no objectification of work apart from its performance ... work cannot be measured separately of relationships' (1990, 160). Thus, to a large extent, labour's value is derived from its role in reaffirming social relations be it in commodity production or the subsistence economy. Universal theories of labour value are unable to capture these relational and non-market dimensions of labour value. As Sillitoe $(2006,143)$ remarks:

It is to force our categories and ideas on others to assume that labour must similarly be seen as the source of value and wealth elsewhere, such as the New Guinea Highlands. It results in inappropriate enquiries, such as attempts to calculate the labour value contributed by people to the things they produce...

Different notions of labour value are therefore clearly more valued among oil palm smallholders. As Miller observes not only does a community define for itself what value is, but it also 'creates the conditions under which it can be created or destroyed' $(2008,1123)$. 
How registers of value are contested in the process of wider economic and social change is discussed next.

\section{Revaluing labour}

Whilst cooperative labour strategies underpin the production strategies of the vast majority of village oil palm producers, changing and contested notions of labour value are undermining cooperative oil palm production strategies among migrant households on the LSS. Beginning in the early to mid 1990s on the Hoskins LSS, second generation co-resident married sons increasingly began challenging the wok bung wantaim cooperative production strategy, which started to give way to a new production strategy where harvesting and the associated income were rotated on a monthly schedule amongst individual co-resident households (Koczberski et al., 2001). This new production strategy, known locally as makim mun (literally marked month), coincides with the milling company's monthly payments to smallholders. Under the makim mun production strategy, labour is drawn predominantly from the household whose month it is to harvest, with occasional recruitment of additional labour from co-resident or off-block households. There is less inter-household cooperation in harvesting, and typically, work groups are smaller than those following the cooperative, wok bung wantaim production strategy. At Hoskins, 50\% of LSS blocks identified makim mun as their main production strategy in 2002.

LSS blocks that have adopted the makim mun production strategy tend to have a larger resident population and a greater number of co-resident households than blocks practising the wok bung wantaim strategy (Table 2). The LSSs were established on the basis of individual lease holdings over fixed areas of land and a set of land tenure regulations that specified the cash crop to be cultivated and the area of land reserved for food production. Under such rigid constraints there was no scope for crop substitution and little opportunity for supplementary cash cropping in the area of land reserved for food gardens.

Table 2. Mean population and mean numbers of households per LSS block by oil palm production strategy at Hoskins.

\begin{tabular}{|l|c|c|}
\hline LSS & Wok Bung Wantaim & Makim Mun \\
\hline Mean population & 12.2 & 14.7 \\
\hline $\begin{array}{l}\text { Mean numbers of } \\
\text { households }\end{array}$ & 2.5 & 3.5 \\
\hline
\end{tabular}

(Source: Koczberski and Curry, 2003)

Thus, when population and economic pressures emerged over time, the range of agricultural responses open to LSS smallholders was limited, and social conflict inevitably arose (Koczberski, 2011). The wok bung wantaim production strategy that had dominated smallholder production came under pressure on several fronts, not least by the demands and aspirations of a generation of younger men who began challenging the foundations upon which this production strategy relied: centralised control over labour and income, and indigenous norms and values, particularly those relating to the indigenous concepts of labour value. In the contest between generations, between leaseholder and ordinary block resident, between the individual and the group, between modernity and tradition, and between market and indigenous economic relations and values, social stresses were heightened and the makim mun production strategy was born. By rotating control of production and income among coresident households many of the concerns of the younger men were addressed and the strategy began spreading rapidly in the densely populated LSS. 
The shift to the makim mun production strategy illustrates changing and contested notions of labour value in three main ways. First, under the makim mun strategy there is less opportunity through oil palm production to affirm inter-household relationships and express extra-familial solidarity and cohesiveness. As mentioned earlier, the makim mun strategy is characterised by more individualised production strategies with much less recruitment of labour from coresident households.

Second, the wok bung strategy, where the mobilisation and organisation of harvesting labour and the distribution of income are centrally controlled by the head of the block (father/blockowner), is replaced by a rotating set of household heads each month making decisions regarding labour and income distribution. Thus, households act more autonomously as the leaseholder (father/blockowner) relinquishes some authority over labour and income flows on the block to his married, co-resident sons. Whilst the head of the block may still ensure that harvest months are rotated fairly amongst co-resident households and make farm investment decisions, his authority is diminished as decisions over labour and income distribution become the responsibility of the household head allocated that month's production.

Third, under the makim mun strategy, labour value becomes more market-based and is determined less by indigenous registers of labour value associated with the gift economy. Income is retained by the male household head allocated that month's harvest rounds with labour transactions largely excised from the non-market economy and its alternative ways of valuing labour, so that remuneration of labour is more likely to reflect market rates of pay. There is also limited in-kind payment for labour, and if food is cooked for the work group it is usually in addition to, not in lieu of, cash payments for labour. Whilst labour is still partly embedded in a framework of reciprocity, a much stronger element of commodification is present and market relations begin to be privileged over indigenous economic and social relations of production and exchange. Key differences between the two production strategies are summarised in Table 3.

Ironically, the transition to a more market based value of labour through adoption of the makim mun strategy is associated with lower productivity. ${ }^{5}$ This is because the capacity to mobilise labour under this strategy is reduced, particularly if the makim mun strategy emerged in response to prolonged conflict between co-resident households. When co-resident households adopt the makim mun strategy and act more autonomously, typically the family whose month it is to harvest is unable to call on co-resident households for labour. With less inter-household cooperation, harvesting work groups are usually smaller and therefore less of the crop is harvested in the three-day harvesting window, especially during high crop periods. The total income and production for the block is therefore less than it would be under a wok bung wantaim strategy. ${ }^{6}$

Figure 2 shows the proportions of oil palm crop harvested by settlers and villagers ( $Y$ axis) against different quantities of crop available for harvesting ( $X$ axis). As stated above, settlers are much more dependent than villagers on oil palm with an average productivity level of $60 \%$ of plantation production over the five year period. In contrast, villagers, with an average productivity level of $38 \%$ of plantation production over the same period, are much more fickle producers. Turning to look at settlers' productivity in more detail, it can be seen that as the quantity of oil palm fruit available for harvesting increases, as measured by plantation production on the $X$ axis, the proportion of the crop they are able to harvest declines. That is, 
there is an inverse relationship between crop availability and settlers' productivity $(R 2=$ 0.63 ; this is a much stronger relationship than between productivity and price ${ }^{7}$ ).

Despite the high population density of the LSS and a large pool of potential co-resident labour, settlers are unable to mobilise the extra labour required for harvesting when crop availability rises. In contrast, in the village context where the wok bung wantaim strategy is by far the dominant production strategy, villagers harvest a larger proportion of the available crop as the amount of crop on the palms increases (Figure 2). For villagers, there is a positive relationship between crop availability, as measured by plantation production, and productivity $(R 2=0.53)$. By practising the wok bung wantaim labour strategy, village producers are able to expand the size of their labour groups at a rate that exceeds the increase in the amount of crop on the palms. Villagers, who can easily mobilise labour are therefore more motivated to organise harvesting work groups during high crop periods, but rapidly lose interest, or shift their labour to other livelihood activities, when there is less crop on the palms to be harvested. In effect, high crop periods are an opportunity for the performance of labour to realise the social value of labour, while such opportunities are more constrained during low crop periods.

Table 3

Table 3. Wok bung and Makim mun production strategies compared (Source: Koczberski, 2011).

\begin{tabular}{|c|c|}
\hline Wok bung & Makim mun \\
\hline $\begin{array}{l}\text { Harvesting labour is drawn from all co- } \\
\text { resident households. }\end{array}$ & $\begin{array}{l}\text { Less inter-household co-operation as } \\
\text { labour is drawn largely from the } \\
\text { household whose turn it is to harvest. }\end{array}$ \\
\hline $\begin{array}{l}\text { Organisation of harvesting labour and } \\
\text { the distribution of income is controlled } \\
\text { by the head of the block } \\
\text { (father/blockowner). }\end{array}$ & $\begin{array}{l}\text { Organisation of harvesting labour and } \\
\text { the distribution of income is largely } \\
\text { controlled by a different household } \\
\text { head each month. }\end{array}$ \\
\hline Highly centralised form of production. & $\begin{array}{l}\text { Devolution of the authority and control } \\
\text { of the male leaseholder or head of block } \\
\text { to married co-resident sons. }\end{array}$ \\
\hline $\begin{array}{l}\text { Labour remuneration is mediated by } \\
\text { indigenous cultural norms and values. }\end{array}$ & $\begin{array}{l}\text { Labour remuneration is governed less } \\
\text { by cultural norms and more in line with } \\
\text { market values. }\end{array}$ \\
\hline $\begin{array}{l}\text { Maintains given generational } \\
\text { relationships and authority structures. }\end{array}$ & $\begin{array}{l}\text { Socio-political reorganisation of power } \\
\text { and economic relations on the block. }\end{array}$ \\
\hline
\end{tabular}




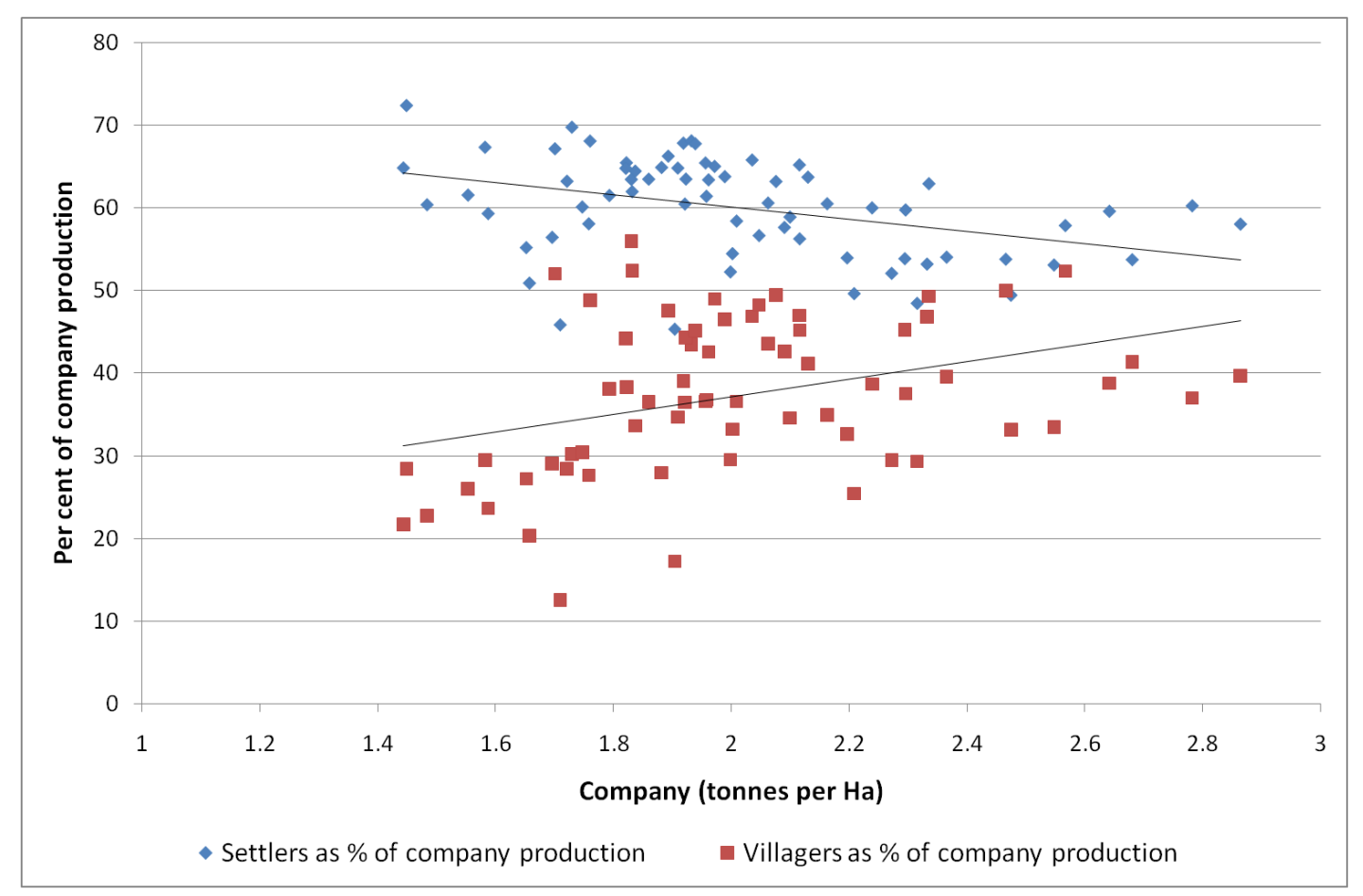

Figure 2. Settler and villager production expressed as a percentage of plantation production.

The shift from wok bung wantaim to makim mun is therefore more than a simple reorganisation of labour in oil palm production. It signals a significant socio-political reorganisation of power and economic relations on a block and an ontological shift in how labour is valued. As production shifts to a more market-based system, different values, authority, and power relations come to the fore which undermine cooperative inter-household labour strategies and the cultural norms and values in which they are embedded. From this perspective, the makim mun strategy signifies a substantive social transformation as adult sons act to dilute indigenous social and economic relations in favour of more market-oriented ones in their attempts to break with past traditions and form new relations of production and exchange. In the process, sons are simultaneously contesting given generational relations and structures of authority and power.

The period in the lead up to the switch from wokbung wantaim to makim mun is often marked by considerable social conflict and tensions amongst family members which become more intense on paydays and in the few days immediately following. Values of labour are contested, sometimes violently, as the older men struggle to maintain the social value of labour in the face of increasing commodification of labour. For many, the transition is from a moral economy of labour to an amoral one in which in which indigenous ways of valuing labour are debased and undermine established social relationships and roles, and there is a marked decline in inter-household cooperation in all spheres of life. Despite the reduction in total production and income for the block with the transition to makim mun, for many block residents, particularly women, the transition represents a successful innovation because it results in a long-term reduction in conflict amongst co-resident families.

In summary, the adoption of the makim mun strategy entails an erosion of indigenous socioeconomic relations and ways of valuing labour in oil palm production with a consequent 
strengthening of market-based relations. Whether or not this change constitutes a permanent shift towards market-based labour relations is difficult to tell, given that throughout PNG indigenous economic forms and cultural values have shown remarkable resilience and an ability to renew and refashion themselves by exploiting new opportunities in the altered political and economic context that is modern PNG (for example, Sahlins, 1972; Maclean, 1989; Nihill, 1989; Goddard, 2000; Imbun, 2000; Connell, 2007). It can be said, however, that the shift to more market-based economic relations associated with the makim mun strategy remains incomplete and ambiguous because a gift element is still present or subsumed within other logics, and can resurface depending on shifting economic and social contexts. Moreover, this shift is more one of degree rather than one involving a full transformation of economic and social relationships.

\section{Discussion and conclusion}

By presenting a more place-based and relational notion of value that emphasises the coconstitution of economy and society the paper highlights three points relevant to developing new theoretical understandings of 'development', processes of commodification and societal change. First, the study shows that concepts of labour value are not static and can involve struggles over how value is defined. The period immediately preceding the transition to makim mun, was often distressing for residents, especially so because in PNG strife and social conflict within the group are often perceived to be the cause of illness and misfortune (Koczberski and Curry, 1999). In addition to the trauma arising directly from social conflict, the rise in more market-based ways of valuing labour exacerbated social stresses within and between families and across generations. Instead of reproducing social and kinship relationships, the new relations of production associated with makim mun eroded the social value of labour, and rather than strengthening relationships amongst families, began to weaken them.

Second, the study suggests that the Theories of Value used to frame much geographical research may not necessarily correspond with the value and values of our research subjects. As Sillitoe $(2006,121)$ puts it,

[t]he capitalist hierarchy depends to a large extent on the sort of work you do and, up to a certain point, the income you receive and hence your material standard of living, and there is a tendency to import these values into interpretations of arrangements elsewhere.

In other words, there may be a disjuncture between research subjects' notions of value and the Theories of Value imposed on them by outside researchers (Sillitoe, 2006). Thus, the concept of a universal source of labour value needs to be re-examined in favour of other more place-based conceptions of labour value that emphasise the relational dimensions of economy and indigenous ways of defining value. This means exposing the various, and sometimes contradictory, forms of value and meanings that invest labour and are associated with different constructions of sociality, personhood and economy.

Exposing these other values involves disassembling the concept of value and labour to highlight labour's social value. This involves what Rigg (2007) terms, theorising 'upwards' by using empirical data from the developing world to inform theory rather than grafting on to the developing world models and understandings of sociality and economy developed in western/ European contexts (see also Yeung and Lin, 2003; Pollard et al., 2009). In this reverse form of theorising, the assumed transformation of indigenous socio-economies into 
market-based production and exchange can be rethought to accommodate the enduring influences of the indigenous socio-economy and its alternative registers of value. As Miller $(2008,1124)$ emphasises, to find out what value is, we must find out what value does, because 'people seem to find their use of the term value, valuable.'

Finally, and related to the previous point, there can be real world consequences when policies and development strategies in the developing world are underpinned by Theories of Value that are not shared by the recipient communities. Miller goes as far as to argue that the adoption of universal bottom-lines of value can undermine a group's welfare because their own systems of value are marginalised. Using the example of Marx's labour theory of value, Miller explains:

... at a structural level Marx's approach can be seen to cause some of the most problematic consequences in the contemporary use of the term. For Marx, grounding value in a bottom line, in his case labour, was the very means to ensure its re-attachment to the welfare of populations. But reviewing uses of the term more generally suggests that such bottom-line approaches almost invariably, whatever their intent, end up taking us away from the integration of value and values. These ... ultimately detract from, rather than enhance, the welfare of populations. This is partly because they take us away from respect for that population's own use of value to express their own sense of welfare (Miller, 2008, 1124).

By paying greater attention to and respect of indigenous registers of value we can avoid devaluing other people's values important for their welfare, but which are so often trampled on, if not destroyed, in the name of development. Hence, the lineal models of socio-economic transformation commonly used in development geography, and which underpin development projects more broadly, would benefit from incorporating notions of hybrid forms of development, ones in which other values and meanings of what it means to be 'developed' can be accommodated. This requires acknowledging that capitalist-style development and market-based development interventions in the developing world are not always aligned with indigenous notions of development and registers of value and, therefore, often fail because they are not taken up when project funding ceases. A better strategy is to identify ways that development initiatives based on market and capitalist style development can be inflected to better serve other types of development, for example, in contexts that enhance the social value of labour.

\section{ACKNOWLEDGEMENTS}

We thank participants in the ASAO conference, Canberra, January 2008, for their feedback on an earlier version of the paper. Joachim Lummani, Phil Moore, Ian Chalmers, Ben Imbun, and the journal referees provided helpful feedback on the draft manuscript. Frederic

Dumortier, formerly of NBPOL, provided some of the production data and assisted with their analysis. We thank staff of PNGOPRA, OPIC, NBPOL, and Hargy Oil Palms Ltd, for their support. Fieldwork was funded by the Australian Centre for International Agricultural Research and the Australian Research Council. We are grateful to Prof. Niels Fold and the Department of Geography and Geology, University of Copenhagen, for hosting us during the main period of writing. 


\section{NOTES}

1. Production data were excluded from plantation and smallholder divisions where large-scale planting or replanting had occurred during this period.

2. Because of the temporal irregularity of the palm census surveys, the palm census data were interpolated from one census survey to the next using equations to smooth the data run through time. There were two palm census surveys during the data period (December 2001 and December 2002), with one before and one after the period of the data run.

3. The mobilisation of cooperative labour groups work is also commonly used by cocoa smallholders in East New Britain Province during the seasonal cocoa 'flush' period (Curry et al., 2007).

4. A variety of indigenous mechanisms for mobilising family, extra-familial and communal labour for large agricultural tasks, have been reported from numerous agricultural societies (for example, Berry, 1993; Netting, 1993; Stone, 1997; 2001; Englund, 1999; Whitehead, 2002).

5. The atomisation of production units means that individual co-resident households are reluctant to cooperate in other oil palm production tasks such as block maintenance tasks, or to invest in farm inputs or loan repayments. Repayments for farm inputs like fertiliser are borne disproportionately by the family whose turn it is to harvest while benefits of higher yields are shared by all co-resident households allocated a harvest month.

6. Preliminary data from Senny Kapia Mendano for Hoskins indicate that harvested tonnes per ha are lower for LSS blocks practising the makim mun strategy than those still following the wokbung wantaim production strategy.

7. Price had a very limited influence on smallholder productivity, particularly among settlers. Price explained only $0.5 \%\left(\mathrm{R}^{2}=0.0055\right)$ of the variation in settlers' production and just $9 \%\left(\mathrm{R}^{2}=0.089\right)$ of the variation in villagers' production. This was over quite a large price range from K51/tonne to K204/tonne. The absence of a significant price response does not mean that it is unimportant for smallholders. During interviews in late 2000 and early 2001 both settlers and villagers complained bitterly about the low oil palm prices prevailing at the time.

\section{REFERENCES}

Amin, A. and Thrift, N., 1995: Institutional issues for the European regions: from markets and plans to socioeconomics and powers of association. Economy and Society 24, 4166.

Bahelt, H. and Glückner, J., 2003: Toward a relational economic geography. Journal of Economic Geography 3, 117-144.

Bainton, N.A., 2011: The Lihir Destiny: Cultural Responses to Mining in Melanesia. AsiaPacific Environment Monograph 5, Australian National University E Press, Canberra.

Banks, G., 1999: Business as usual. In Filer, C. (ed.) Dilemmas of Development. The Social and Economic Impact of the Porgera Gold Mine. Research School of Pacific and Asian Studies, Australian National University, Canberra, 222-259.

Barclay, K., 2006: Between modernity and primitivity: Okinawan identity in relation to Japan and the South Pacific. Nations and Nationalism 12, 117-137.

Berry, S., 1993: No Condition Is Permanent. The Social Dynamics of Agrarian Change in Sub-Saharan Africa. The University of Wisconsin Press, Madison.

Block, F., 2001: Introduction. In Polanyi, K. (ed.) The Great Transformation. Beacon Press, Boston, xviii-xxxviii.

Boggs, J.S. and Rantisi, N.M., 2003: The 'relational turn' in economic geography. Journal of Economic Geography 3, 109-116. 
Cahn, M., 2008: Indigenous entrepreneurship, culture and micro-enterprise in the Pacific Islands: case studies from Samoa. Entrepreneurship and Regional Development 20, 118.

Carrier, J.G. and Carrier, A.H., 1989: Wage, Trade and Exchange in Melanesia: A Manus Society in the Modern State. University of California Press, Berkeley.

Connell, J., 2007: Islands, idylls and the detours of development. Singapore Journal of Tropical Geography 28, 116-135.

Crush, J. (ed.), 1995: Power of Development. Routledge, London.

Curry, G.N., 1997: Warfare, social organisation and resource access amongst the Wosera Abelam of Papua New Guinea. Oceania 67, 194-217.

Curry, G.N., 1999: Markets, social embeddedness and precapitalist societies: the case of village tradestores in Papua New Guinea. Geoforum 30, 285-298.

Curry, G.N., 2003: Moving beyond post development: facilitating indigenous alternatives for 'development. Economic Geography 79, 405-423.

Curry, G.N., 2005: Doing 'Business' in Papua New Guinea. Journal of Small Business and Entrepreneurship 18, 231-246.

Curry, G.N. and Koczberski, G., 2009: Finding common ground: relational concepts of land tenure and economy in the oil palm frontier of Papua New Guinea. The Geographical Journal 175, 98-111.

Curry, G.N., Koczberski, G., Omuru, E. and Nailina, R.S., 2007: Farming or Foraging? Household Labour and Livelihood Strategies amongst Smallholder Cocoa Growers in Papua New Guinea. Black Swan Press, Perth. Retrieved: 14 August 2011 from $<$ http://espace.library.curtin.edu.au:80/R?func=dbin-jump-full\&local_base=gen01era02\&object_id=129445>

Englund, H., 1999: The self in self-interest: land, labour and temporalities in Malawi's agrarian change. Africa 69, 139-159.

Escobar, A., 1995: Encountering Development: the Making and Unmaking of the Third World. Princeton University Press, Princeton, NJ.

Esteva, G. and Prakesh, M.S., 1998: Grassroots Post-Modernism: Remaking the Soil of Cultures. Zed Books, London.

Ettlinger, N., 2003: Cultural economic geography and a relational and microspace approach to trusts, rationalities, networks, and change in collaborative workplaces. Journal of Economic Geography 3, 145-171.

Fajans, J., 1993: Exchanging products: producing exchange. In Fajans, J. (ed.) Exchanging Products: Producing Exchange. Oceania Monograph 43, University of Sydney, Sydney, 1-13.

Foster, R.J., 1995: Social Reproduction and History in Melanesia: Mortuary Ritual, Gift Exchange, and Custom in the Tanga Islands. Cambridge University Press, Cambridge.

Gibson-Graham, J.K., 1996: The End of Capitalism (as We Knew It): A Feminist Critique of Political Economy. Blackwell, Oxford and Cambridge.

Gill, N., 2005: Aboriginal pastoralism, social embeddedness, and cultural continuity in Central Australia. Society and Natural Resources 18, 699-714.

Goddard, M., 2000: Of cabbages and kin: the value of an analytic distinction between gifts and commodities. Critique of Anthropology 20, 137-151.

Granovetter, M., 1985: Economic action and social structure: the problem of embeddedness. American Journal of Sociology 91, 481-510.

Gregory, C.A., 1982: Gifts and Commodities. Academic Press, New York and London.

Hart, G., 2001: Development critiques in the 1990s: culs de sac and promising paths. Progress in Human Geography 25, 649-658. 
Hefner, R.W., 1998: Introduction. Society and morality in the new Asian capitalisms. In Hefner, R.W. (ed.) Market Cultures. Society and Morality in the New Asian Capitalisms. Westview Press, Boulder, CO, 1-38.

Hess, M., 2004: 'Spatial' relationships? Towards a reconceptualization of embeddedness. Progress in Human Geography 28, 165-186.

Hide, R.L., 1981: Aspects of pig production and use in Colonial Sinasina, Papua New Guinea. Unpublished Ph.D. thesis, Department of Anthropology, Columbia University.

Hughes, A., 2005: Geographies of exchange and circulation: alternative trading spaces. Progress in Human Geography 29, 496-504.

Hulme, D., 1984: Land settlement schemes and rural development in Papua New Guinea. Unpublished Ph.D. thesis, James Cook University, Queensland.

Imbun, B.Y., 2000: Mining worker or 'opportunist' tribesmen? A tribal workforce in a Papua New Guinea mine. Oceania 71, 129-149.

Jones, A., 2008: Beyond embeddedness: economic practices and the invisible dimensions of transnational business activity. Progress in Human Geography 32, 71-88.

Kirwan, J., 2004: Alternative strategies in the UK agro-food system: interrogating the alterity of farmers' markets. Sociologia Ruralis 44, 395-415.

Koczberski, G., 2007: Loose Fruit Mamas: creating incentives for smallholder women in oil palm production in Papua New Guinea. World Development 35, 1172-1185.

Koczberski, G., 2011: Smallholder households and the changing agricultural and social landscape of the oil palm land settlement schemes, West New Britain, Papua New Guinea. Unpublished Ph.D. thesis, School of Geosciences, University of Sydney.

Koczberski, G. and Curry, G.N., 1999: Sik bilong ples: an exploration of meanings of illness and well-being amongst the Wosera Abelam of Papua New Guinea. Australian Geographical Studies 37, 230-247.

Koczberski, G. and Curry, G.N., 2003: Sustaining Production and Livelihoods among Bialla Oil Palm Smallholders: A Socio-Economic Study of the Smallholder Sector. Research Unit for the Study of Societies in Change, Curtin University of Technology, Perth. Retrieved: 14 August 2011 from <http://espace.library.curtin.edu.au:80/R?func=dbin-jumpfull\&local_base=gen01-era02\&object_id=19066>

Koczberski, G., Curry, G.N. and Gibson, K., 2001: Improving Productivity of the Smallholder Oil Palm Sector in Papua New Guinea: A Socio-Economic Study of the Hoskins and Popondetta Schemes. Department of Human Geography, Research School of Pacific and Asian Studies, Australian National University, Canberra, Retrieved: 14 August 2011 from <http://espace.library.curtin.edu.au:80/R?func=dbin-jumpfull\&local_base=gen01-era02\&object_id=19097>

Koczberski, G., Curry, G.N. and Imbun, B., 2009: Property rights for social inclusion: migrant strategies for securing land and livelihoods in Papua New Guinea. Asia Pacific Viewpoint 50, 29-42.

Kuehling, S., 2005: Dobu: Ethics of Exchange on a Massim Island, Papua New Guinea. University of Hawaii Press, Honolulu.

Lee, R., 2006: The ordinary economy: tangled up in values and geography. Transactions of the Institute of British Geographers NS 31, 413-432.

Leyshon, A., 1997: Geographies of money and finance II. Progress in Human Geography 21, 381-392.

Leyshon, A., Thrift, N. and Pratt, J., 1998: Reading financial services: texts, consumers, and financial literacy. Environment and Planning D: Society and Space 16, 29-55.

Maclean, N.L., 1989: The commoditization of food: an analysis of a Maring market. Canberra Anthropology 12, 74-98. 
Malinowski, B., 1919: Kula: the circulating exchange of valuables in the archipelagos of Eastern New Guinea. Man 20, 97-105.

Mauss, M., [1925] 1974: The Gift. Routledge and Kegan Paul, London.

McKay, D., 2009: Performing economy differently: exploring economic personhood and local economic diversity. The Australian Journal of Anthropology 20, 330-346.

Miller, D., 2008: The uses of value. Geoforum 39, 1122-1132.

Minnegal, M. and Dwyer, P.D., 2007: Money, meaning and materialism: a Papua New Guinean case history. Working Paper No. 2/2007. School of Social and Environmental Enquiry Working Papers in Development, University of Melbourne, Melbourne.

Misztal, B.A., 1996: Trust in Modern Societies: the Search for the Bases of Social Order. Polity Press, Cambridge.

Modjeska, N., 1982: Production and inequality: perspectives from central New Guinea. In Strathern, A. (ed.) Inequality in New Guinea Highlands Societies. Cambridge University Press, Cambridge, 50-108.

Nabudere, D.W., 1997: Beyond modernization and development, or why the poor reject development. Geografiska Annaler 79, 203-215.

Nederveen Pieterse, J.N., 1994: Globalisation as hybridisation. International Sociology 9, 161-184.

Nederveen Pieterse, J.N., 2000: After post-development. Third World Quarterly 21, 175-191.

Netting, R.M., 1993: Smallholders, Householders: Farm Families and the Ecology of Intensive, Sustainable Agriculture. Stanford University Press, Stanford.

Nihill, M., 1989: The new pearlshell: aspects of money and meaning in Anganen exchange. Canberra Anthropology Special Issue: Culture and Development in Papua New Guinea $12,144-160$.

Nihill, M., 1991: Money and 'Moka': men, women, and change in Anganen mortuary exchange. Journal of Polynesian Society 100, 45-69.

Perreault, T., 2003: 'A people with our own identity': toward a cultural politics of development in Ecuadorian Amazonia. Environment and Planning D: Society and Space 21, 583-606.

Platteau, J., 1994a: Behind the market stage where real societies exist. Part I: the role of public and private order institutions. The Journal of Development Studies 30, 533-577.

Platteau, J., 1994b: Behind the market stage where real societies exist. Part II: the role of moral norms. The Journal of Development Studies 30, 753-817.

Polanyi, K., 1944: The Great Transformation. Rinehart, New York.

Polanyi, K., Arensberg, C. and Pearson, H. (eds), 1957: Trade and Markets in Early Empires. Glencoe Free Press, New York.

Pollard, J., McEwan, C., Laurie, N. and Stenning, A., 2009: Economic geography under postcolonial scrutiny. Transactions of the Institute of British Geographers NS 34, 137142.

Rahmena, M. and Bawtree, V. (eds), 1997: The Post-Development Reader. Zed Books, London.

Rigg, J., 2007: An Everyday Geography of the Global South. Routledge, Oxon.

Sahlins, M., 1972: Stone Age Economics. Aldine-Atherton, Chicago.

Sahlins, M., 2005: The economics of develop-man in the Pacific. In Robbins, J. and Wardlow, H. (eds) The Making of Global and Local Modernities in Melanesia. Humiliation, Transformation and the Nature of Cultural Change. Ashgate Publishing Limited, Hampshire, 23-43.

Sidaway, J.D., 2007: Spaces of postdevelopment. Progress in Human Geography 31, 345361. 
Sillitoe, P., 2006: What labour engenders: women and men, time and work in the New Guinea Highlands. The Asia Pacific Journal of Anthropology 7, 119-151.

Simon, D., 1998: Rethinking (post)modernism, postcolonialism, and posttraditionalism South-North perspectives. Environment and Planning D - Society and Space 16, 219245.

Simon, D., 2007: Beyond antidevelopment: discourses, convergences, practices. Singapore Journal of Tropical Geography 28, 205-218.

Smith, A. and Stenning, A., 2006: Beyond household economies: articulations and spaces of economic practice in postsocialism. Progress in Human Geography 30, 190-213.

Stone, G.D., 1997: Predatory sedentism: intimidation and intensification in the Nigerian savanna. Human Ecology 25, 223-242.

Stone, G.D., 2001: Theory of the square chicken: advances in agricultural intensification theory. Asia Pacific Viewpoint 42, 163-180.

Strathern, A., 1982: The division of labour and processes of social change in Mount Hagen. American Ethnologist 9, 307-319.

Strathern, M., 1990: The Gender of the Gift: Problems with Women and Problems with Society in Melanesia. University of California Press, Berkeley.

Swedberg, R., 1994: Markets as social structures. In Smelser, N.J. and Swedberg, R. (eds) The Handbook of Economic Sociology. Princeton University Press and Russell Sage Foundation, Princeton and New York, 255-282.

Thomas, N., 1991: Entangled Objects: Exchange, Material Culture and Colonialism in the Pacific. Harvard University Press, Cambridge.

Thornton, A., Kerslake, M.T. and Binns, T., 2010: Alienation and obligation: religion and social change in Samoa. Asia Pacific Viewpoint 51, 1-16.

Thrift, N., 1996: Spatial Formations. Sage, London.

Thrift, N. and Olds, K., 1996: Refiguring the economic in economic geography. Progress in Human Geography 20, 311-337.

Turner, S., 2007: Small-scale enterprise livelihoods and social capital in Eastern Indonesia: ethnic embeddedness and exclusion. The Professional Geographer 59, 407-420.

Van der Grijp, P., 2004: Identity and Development. Tongan Culture, Agriculture, and the Perenniality of the Gift. KITLV Press, Leiden.

Waddell, E.W. and Krinks, P.A., 1968: The organisation of production and distribution among the Orokaiva. New Guinea Research Bulletin, Number 24.

Weiner, A., 1992: Inalienable Possessions: the Paradox of Keeping-While-Giving. University of California Press, Berkeley.

Whitehead, A., 2002: Tracking livelihood change: theoretical, methodological and empirical perspectives from North-East Ghana. Journal of Southern African Studies 28, 575-598.

Yeung,W.C.H., 2005: The firm as social networks: an organisational perspective. Growth and Change 36, 307-328.

Yeung, W.C.H., 2009: Transnationalizing entrepreneurship: a critical agenda for economic geography. Progress in Human Geography 33, 210-235.

Yeung, W.C.H. and Lin, G.C.S., 2003: Theorizing economic geographies of Asia. Economic Geography 79, 107-128.

Zukin, S. and DiMaggio, P. (eds), 1990: Structures of Capital. The Social Organization of the Economy. Cambridge University Press, Cambridge. 